\title{
ОСОБЛИВОСТІ СТРУКТУРИ І СЕМАНТИКИ НАЗВ ПРЕДМЕТІВ (КОНФІКСАЛЬНІ ІМЕННИКИ НА -ОК)
}

Качайло К. А. Особливості структури і семантики назв предметів (конфіксальні іменники на -ок)

У статті досліджено в діахронічному аспекті особливості словотвірної структури і семантики іменникових конфіксальних дериватів на -ок - назв предметів, що зафіксовані в середньо- та новоукраїнській мові. У творенні таких похідних слів бере участь сімнадцять конфіксальних морфем із постпозитивною частиною -ок. 3 огляду на це виклад матеріалу здійснено в напрямку до зменшення продуктивності словотвірних типів.

Ключові слова: конфіксація, конфікс, конфіксальний дериват. 
Качайло К. А. Особенности структуры и семантики названий предметов (конфиксальные существительные на -ок).

В статье исследованы в диахроническом аспекте особенности словообразовательной структуры и семантики именных конфиксальных дериватов на -ок - названий предметов, которые зафиксированы в средне- и новоукраинском языке. В образовании таких производных слов берет участие семнадцать конфиксальных морфем с постпозитивной частью -ок. С учетом этого изложение материала осуществлено в направлении к уменьшению продуктивности словообразовательных типов.

Ключевые слова: конфиксация, конфикс, конфиксальный дериват.

Kachaylo K.A. Features of structure and semantics of the names of subjects (confixal nouns with -ок).

The article deals with the features of word formation structure and semantics of nominal confixal derivatives with -ок - names of subjects in diachronical aspect, which are fixed in middle and new Ukrainian language. Seventeen confixal morphemes with postposition part ок takes part in formation of such derivative words. In view of it the statement of a material is carried out in a direction to reduction of efficiency word formation types.

Key words: confixation, confix, confixal derivative.

Українські мовознавці приділяли значну увагу дослідженню словотвірної структури та семантики іменника як у діахронічному, так і синхронічному аспектах. До питань словотворення цієї частини мови зверталися П. Білоусенко, В. Горпинич, С. Карпіловська, Н. Клименко, І. Ковалик, М. Плющ та інші. Однак конфіксальні іменники на -ок ще повністю не досліджені, що визначає актуальність цієї роботи.

Мета статті: вивчити в діахронічному аспекті особливості структури i семантики назв предметів у межах конфіксальних іменників на -ок, оскільки порівняно з давньоруськоукраїнським періодом, у XIV-XXI століттях спостерігається збільшення назв предметів, що утворюються за допомогою конфіксів із постпозитивною частиною -ок.

За даними фактичного матеріалу, найбільшу кількість складає лексико-словотвірна група найменувань предметів, які лише за деякими ознаками подібні до названих твірною іменниковою основою або не повністю $є$ тим, що названо мотивувальним словом. У творенні назв предметів бере участь більше п'ятнадцяти конфіксальних морфем на -ок, тому подальший виклад матеріалу здійснено в напрямку до зменшення продуктивності словотвірних типів.

Конфікс пол(полу-)-...-ок. Найменування предметів, до формальної структури яких входить конфікс пів-/пол(ъ)-/(полу-)-...-ок(b), поділяються на дві великих групи:

1. Перші номени предметів, які є наполовину меншими від тих, щзо названі твірною основою, фіксуються в обстежених пам'ятках XVI століття: полмисковъ (1575 АрхЮЗР 1/I 54) “глибока глиняна тарілка, яка за місткістю відповідає половині миски”, полумисок (СУМ VII 101) “різновид столового посуду, що має вигляд неглибокої миски або глибокої тарілки”, “неглибока миска" (2000 СЗГ II 68); полбочокъ, полубочокъ (XVI IKIC) “де- 
рев’яна посудина 3 дощок, скріплених кільцями, місткість якої складає 1015 відер”, полубичок (2003 УГР 685) “діжка, кадіб”, полібочок (1909 Д 232), полібічок (1909 Дубр 155) “діжка, наполовину менша за звичайну”; полубортокъ (XVI IKIC) “невелика колода для бджіл” (бортъ “дерево з вуликом, колода для бджіл”); полбарилокъ (XVI IKIC) “дерев’яна посудина, зроблена $з$ дощок, обхвачених кільцями” (барило “бочка"), півбарилок (1926 ПУРС 161) “те саме”; полукішок (1886 Ж 693) “плетений кузок” (кошъ “вид плетеної корзини для ручної поклажі”), полупішок (1984 O II 108) “кіш на возі, плетений кусок воза); niўтопорок (1900 ДолГов 114) “знаряддя праці менше від сокири, має дві заточені сторони"; піўскринок (1900 ДолГов 114) “шухляда у скрині на всю ширину верхньої частини”.

У середньоукраїнських джерелах віднаходимо поодинокі назви транспорту та його елементів: полукомжжокъ (1552 Торг 81) “річкове судно вантажопідйомністю близько 5 лаштів" (комжга “найпоширеніший тип сплавного судна без щогл, прямокутної форми, вантажопідйомністю близько 10 лаштів /лашт - міра ваги на річковому транспорті, 1 лашт $=120$ пудів”); полудрабок (1882 ФП 200; 2000 ГГ 323) “бік возового ящика, утворений за допомогою поздовжніх і поперечних жердин на зразок драбини” (драба “великий решітчастий віз для перевозки сіна”) або “одна 3 двох бічних ліскоподібних частин короба воза” (2004 Матіїв 28), “частина воза, що має вигляд ящика” (1960 СПГ 78); полугарбок (1960 СПГ 78) “віз, яким возять сіно, снопи, менший за гарбу” (гарба "віз для перевезення містких матеріалів”); полутрямок (1990 ТЛП 121) “поперечна переводина” (трям “балка, перекладина").

Наявні з цією морфемою й деякі назви одиниц̧ь та предметів вимірювання: полумєрокъ (1489 ССУМ II 187) “міра місткості рідких та сипучих тіл” (мєра “предмет, яким щось наміряють; мірка"), полумирок (1653 АрхЮЗР 1/XI 453), полумярок (1665 АрхЮЗР 1/VI 477); полуквартокъ (XVI IKIC) "посудина для пиття, що за місткістю дорівнює половині кварти" (кварта "міра рідини, восьма або десята частина відра"); полукуфокъ (XVI IKIC) “міра рідини в 15 кварт" (куфа “чан, бочка місткістю в 30 кварт”); півсоток (1886 Ж 636) “половина сотні” (сотня “певна кількість чогось, що дорівнює числу сто”); полумацььок (1886 Ж 693; СУМ VII 101; 1984 O II $108)$ “міра ваги сипучих тіл у 25 кг або дерев’ яний посуд місткістю в 25 кг” (мацуа “міра ваги зернових, що дорівнює 50 кг”); полусеток (1886 Ж 694) “одиниця вимірювання полотна в 50 аршинів” (сеть “одиниця вимірювання полотна в 100 аршинів”); півлатерок (1984 О II 64) “одиниця виміру дров в 1-2 кубометри” (латер “одиниця виміру дров у 2-4 кубометри”).

В обстежених джерелах зафіксовані найменування грошових одиницьь, які за вартістю вдвічі менші від тих, що названі твірною основою: полугрошокъ (1494 Торг 38) “грошова одиниця, яка за вартістю дорівнює половині гроша” (грошь “срібна грошова одиниця”); польгрошокъ (1582 АрхЮЗР 1/I 155) “те ж саме”; полталярок (XVI IKIC) “старовинна польсько-литовська 
монета вартістю у 65 копійок срібла або 1 гульден” (таляр “монета у 2 гульдени”), а також інші похідні: півскирток (1886 Ж 636) “скирта, удвічі менша за звичайну"; полустіжск (1893 УмСп 989) “половина стогу”; півдудок (ЛексФр 166) “музичний інструмент, сопілка”; піўкопок (1912 Бат 284) “30 снопів скошеного або зжатого хліба, складених колоссям усередину й прикритих одним снопом зверху" - полукопокъ (1886 Ж 693) (копа — “60 снопів, складених у такий же спосіб”); півплящок (1918 ІвШ 48) “посудина місткістю в половину пляшки" (пляха “сулія, велика посудина").

2. У XVI столітті з конфіксом пів-/пол(b)-/(полу-)-...-ок(b) вперше зафіксовані найменування предметів, які є подібними до тих, щзо названі вивідною основою: на позначення одягу та його деталей виступають нечисленні іменники, а саме: полуботокъ (XVI IKIC) “взуття, у множині чоботи 3 короткими халявами" (боть “чобіт 3 високими халявами"); $n y(л)$ чамаро(к) (1650 ДМ 194) “короткий хутряний чоловічий одяг” (чама$p a$ “верхній чоловічий одяг типу кожуха"); півчобіток (СУМ VI 390) "те саме, що півчобітки - жіночі чоботи з короткими халявами"; полуботки), а також інші деривати: полутабинокъ (1861 Закр 468), полутабенокъ (1893 УмСп 1012) “старовинна гладенька шовкова тканина” (табинъ “вид тканини”); півшкурок (СУМ VI 390) “шкура молодого бичка, яка за розмірами дорівнює половині шкіри дорослої тварини”; пувшорок (2000 СЗГ II 98) “спеціально пошитий ошийник, у якого один ремінь проходить під передніми лапами собаки” (жори або шора (гуц.) “ремінна упряж”), пор. півиорок (2004 Матіїв 48) “поперечний ремінь, що йде через хребет коня від посторонки до посторонки”.

Конфікс о-...-ок. 3 кінця XVI століття обстежені джерела засвідчують назви предметів побуту, інструментів та їх частин, які прилягають впритул до того, щзо позначено твірним словом: адверками (1564 КартТимч) “боковий або верхній брус рами дверей” (пізніше це похідне почало співвідноситися із префіксальним іменником одвір); окрайок (1886 Ж 565) “край дошки або кінець ниви, де розвертаються 3 плугом та бороною”, осередок (2000 ГГ 313) “матеріал для клепки”; ошийок (1886 Ж 589) “комір, частина одягу, що обрамляє шию; нашийник”; огузок 1976 БукГов 6 89) “мішок, до половини наповнений чимось; клунок, який звисає 3 плеча до рівня задньої частини тіла людини — біля гузи”; оденок (Гр III 38) “підстилка під кладками снопів, сіна”, “стіжок сіна; спеціальна підстилка (з соломи, хмизу) під великими кладками снопів, сіна; нижня дошка у возі” (2004 Матіїв 44; 2005 СБГ 361); обніжок "перекладина між ніжками (стола, стільця)" (УРС 1926 501); обрамок (СУМ V 562) “те, чим обрамляється щонебудь, рамка” (можлива мотивація дієсловом обрамляти, у такому разі це суфіксальний іменник); опалок (1990 Зел 26) “сітчаста торба для годування коней, яка прилаштовується до палиці"; обічок (1984 АУМ I 76) “обичайка, обід у ситі" (очевидно, від бік “певна сторона чогось”), обальок (2000 СЗГ II 3) “балка у перекритті хати, до якої кріпляться дошки стелі” від балка 
“певним чином оброблена дошка"; одвірок (2000 ГГ 312) “брус дверної скриньки”; обполок (2002 СУСГ 146) “крайня дошка з розпиляної вздовж зовнішньої частини колоди”; обшарок (2005 СБГ 359) “спеціальний інструмент для округлення заліза”; окулок (2005 СБГ 365) “конфорка” (кулка “чавунні кільця закривати отвори на плиті”).

Помітну групу складають найменування предметів, які неповною мірою виявляють ознаки того, щуо названо твірною іменниковою основою: очіпок (1860 Б-Н 268) “один із видів тяжкого чепця одружених жінок або вдів, який покривають, як правило, наміткою (грубою тканиною, схожою 3 покриттям монашок)”; опалянок (1886 Ж 570) “невеликий корж”, пор. паляниця; облавок (Гр III 13; СУМ V 517) “борт корабля” (лава “вузький місток, колода, перекинута через воду для переходу”); оскирдок (Гр III 68) "маленька скирда"; опасок (Гр III 56) "ремінь для носіння бандури через плече", “пояс (чоловічий)" (УРС 1926 513; СУМ V 703), “мотузка, яку пришивають до спідниці і якою спідниця утримується на тілі” (2004 Матіїв 38); опупок (УРС 1926 516) “зав’язь плода”, пор. пуп 'янок; ошкварок (19581960 ЛАЗ 169) “один із підсмажених шматочків сала невеликого розміру” (шквара “спека або шкварка"); окіпок (СУМ V 663) “невелика копа; полукіпок”; опліток (СУМ V 710) “ліса, тин”; ошкалок (2004 Бевка 96) “невелика тріска, скіпка" (икалка “скалка, тріска, скабка”); окрушок (2005 СБГ $365)$ “залишок нарізаного скибками хліба, крихти”, “перша відрізана від паляниці скибка” (2000 СЗГ II 12); оринок (2005 СБГ 368) “дитячий горщик” (очевидно, від ринка “невеликий глиняний горщик”).

Конфікс під-...-ок. 3 середньоукраїнського періоду засвідчені назви предметів, які призначені бути нижче, серед або в тому, на щзо вказує твірна іменникова основа, наприклад: подножокъ (XVI-п.п.XVII IKIC) “жердка ткацького верстату, яку слід натискати ногою, щоб розтягти нитченицею нитки основи”; подпрасокъ (XVI-П.П.XVII IKIC) “пристрій, на який ставлять праску під час прасування"; підситок (1882 ФП 196) “посуд під решетом при якійсь роботі”; підскринок (1886 Ж 49) “нижня частина скрині зі спеціальною шухлядкою”; пид’исокъ (1860Б-Н 89), підісок (1893 УмСп 588) / nid ‘̈скк (1952 Мельн 89) “залізна штаба під дерев’яною віссю (у возі)”, nidiсок (2005 СБГ 418) “кочерга або залізний гачок у вигляді кочерги” та niдoсок, пудусок (2004 Матіїв 28) “залізна пластинчаста скобка, яка підбивається на дерев’яну вісь, де обертається колесо, щоб запобігти зносові осі”; nidмyрок (Гр III 172) “основа будівлі, споруди”, у переносному значенні “те, що становить основу, початок чого-небудь” або “основа будови, споруди, зроблена $з$ каменю, цегли, бетону і т. ін.; фундамент, підвалини” (СУМ VI 460); підсошок (Гр III 180) “підпора тину або огорожі” (соха “роздвоєна на одному кінці палиця”); підкольінок (1912 Верх 246) “те, що прилаштоване в колінній впадині (у медицині — валок) або сама колінна впадина”; підчопок (1984 О II 72) “дерево під чопами, що над ним ходить вал (у млині)” (чоп “зубець колеса машини”); підгрифок (1971 СМТ 76) “деталь струнних ін- 
струментів, до якої прикріпляються нижні кінці струн”; підголовок (2005 СГГ 139) “те, що під головою (подушка або підкладка)".

За допомогою конфікса пiд-...-ок утворюються й найменування предметів домашнього вжитку, побутових пристроїв та їх деталей, які лише за деякими ознаками подібні до тих, що названі твірною іменниковою основою: підмашинок (1874 Левч 70) "вітряний млин з елементами механізації; підрешіток (1874 Левч 177) “різновид густого решета”; підкульок (1886 Ж 643) “малий куль, як правило, в половину менший за звичайний”; підситокъ (1902 Вас 32) "сито, що за розмірами $є$ меншим від звичайного i вміщує приблизно половину мірки"; підбурок (Гр III 160, 2004 Матіїв 55) “залізний гак із довгою дерев'яною ручкою для витягання з води великої риби, найчастіше сома"; підсумок (1927 ПТ 217) “невелика шкіряна сумка, яку носять на поясі”, пудсумок (2000 СЗГ II 103) “невелика сумка для мисливських патронів"; підрамок (СУМ VI 489) “рамка, на яку натягується полотно для малювання картини".

Конфікс при-...-ок. Найменування предметів фіксуються 3 XVIII століття. Значення колишнього прийменника при зумовило розгалуженість семантики таких номенів: 1) “предмет, розташований біля того, що назване мотивувальним словом"; 2) “предмет, менший порівняно 3 тими, які позначені вивідним словом".

Перша група дериватів із лексико-словотвірним значенням "предмет, розташований біля того, що назване мотивувальним словом", почала своє становлення у XVI столітті й остаточно сформувалася в сучасній мові. Наприклад, предмети домашнього вжитку позначені такими дериватами: прилавокъ (1776 ДНМ 211) “частина нерухомої лави в українській хаті під стіною від дверей до кутка", прилавок (СУМ VII 653) “спеціальний стіл для торгівлі в крамниці, буфеті, на базарі і т. ін.”; прискринокъ (1860 Б-Н 300) “маленький ящичок у верхній частині скрині на боковій стінці, призначений для зберігання дрібних речей або коштовностей”, прискрин'ок (Козачук 1991, 121), прискринок (2000 СЗГ ІІ 89) “невелика шухляда у скрині для одягу”; призадок (1879 Павл 889) “поличка для діжки з водою або квасом, яка розташована в задній частині воза"; приголовок (1886 Ж 742) “пелюшка під голову”, “колода, при якій вогонь кладуть” (2000 ГГ 327); npuрамок (1886 Ж 755) “деталь рами вікна, яка вставляється в раму - закладну, глуху, замуровану”.

3 другої половини XIV століття натрапляємо на поодинокі назви елементів одягу: приполокъ (1377 ЛЛ 64) “частина одягу, пола"; приспинок (1879 Павл 906) “частина одягу, що прикриває спину”.

У XVI столітті з'являються перші номени інструментів та їх деталей, а саме: притрубокъ (1582 АрхЮЗР 6/1 122) “коротка трубка, що служить відводом від основної труби"; притрубок (1893 УмСп 1030) “бокова частина труби (музичного інструмента)"; присішок (1931 ВТ 69) “підпорка, стовпчик" (соха "роздвоєна на одному кінці палиця"); прикубокъ (1879 
Павл 893) “невеликий перегонний куб у виноробстві, що знаходиться між кубом і холодильником"; приструнок (УРС 1926 640; СУМ VII 47) “коротка струна на бандурі або кобзі”, а також знаходимо назви деталей сільськогосподарського транспорту: приколибок (1984 О II 139) “дошки спереду колиби для захисту від вітру" (колиба “спеціальний віз, пристосований для кочового життя" або “вівчарська хата на полонинах"); прикозьолок (1984 ДзПА 82) “деталь, розташована біля невеликої крокви, якою накривається верх солом'яної покрівлі” (козел, козьол “з'єднані в горішній частині під кутом два дрючки, якими укріплюють, притискають верх солом'яної покрівлі”); приботок (1993 Ліпкевич 132) “верхня частина боті, до якої кріпляться бортові дошки” (ботя “дрючок”, бот “судно”).

Початок формування другої нечисельної групи найменувань із лексико-словотвірною семантикою "предмет, менший порівняно з тими, які позначені вивідним словом" припадає на XVII століття. Сюди відносимо назви предметів домашнього вжитку: прикадок (УРС 1926 628) "невелика бочка" (када "бочка для вина"), а також найменування кінської упряжі, одягу та їх частин: приуздок (1886 Ж 762) “деталь кінської упряжі, яка надягається на голову коневі” (узда “вуздечка”); приплаток (1958-1960 ЛАЗ 57) “жіночий фартух або шматок тканини, з якого шитимуть фартух” (плат “великий шматок тканини”).

Конфікс за-...-ок. Номени предметів, щзо знаходяться позаду того, що названо мотивувальним словом, датовані другою половиною XVI століття. Наприклад, назви предметів побуту: заголовокъ (1575 АО 55), загововок (2002 СУСГ 80) “подушка"; затыллокъ (1606 КартТимч) “задня частина чи сторона чогось”, затилок (1990 Сизько 35) “дерев'яна планка 3 дірками на краях, яка надягалася ззаду й спереду дерев'яного воза на полудрабки" або "тупе ребро леза ножа" (2000 СЗГ I 178); загривокъ (1855 CMН 124) “хліб, який виріс на ниві полоскою вище від іншого", завісок (Гр II 19) "залізний брусок у возі, прибитий за віссю для того, щоби колесо не терло плеча, на якому стоїть ящик воза"; загвіздок (Гр II 26) “кілочок або цвях, який заважає кінцю палиці пройти назад з отвору”; заріжок (Гр II 89) “останній кусок шкіри, що знаходиться перед рогами”; заглемездок (УРС 1926 244) “предмет, який зроблено неохайно” (діал. глемезд “щось негарне, неохайне"); заденок (1952 Мельн 79; 2005 СБГ 121) “задня сторона ящика на возі” та "верхнє дно бочки" (2000 ГГ 277); закрилок (1971 И 235) “спеціальний пристрій у літака, що знаходиться позаду крила"; зачілок (2000 СЗГ I 180) “причілок хати”; запічок (2005 СГГ) “лежанка на печі чи біля печі”; застілок (2005 СГГ 64) “ліжечко поза столом”.

3 XVIII століття нечисленні похідні виступають найменуваннями елементів одягу: запоясокъ (XVIII КартТимч) “фартух"; заколінок (1886 Ж 250) "спеціальний предмет, який прилаштовують за коліном (у медицині валок)"; засобок (Гр II 99) “задня частина сорочки або зборки на спині кожуха вверх від таліі” (утворене від зворотного займенника себе в орудному 
відмінку: за собою); зарукавок (1928 Елек 62) “злучник, муфта, рукав”, "манжета" (СУМ III 297).

Конфікс на-...-ок. У середньоукраїнській мові з'являються найменування предметів, які в просторі розташовуються зверху по відношенню до того, щзо названо твірною основою. Серед іменників 3 формантом на-...-ок виокремлюємо, наприклад: пристосування для різних частин людського тіла, елементи одягу: наперстокъ (сер.XVII СлЛекс 471; СУМ V 141) “металевий ковпачок, що надягається на палець для зручності пересування голки під час шиття”, “деталь кісся, ціпа” (2005 СГГ 111); наголовок (1886 Ж 471) “ковпак капелюха або дитячий чепчик”, “головний убір" (2005 СГГ 109) та “дитячий чепчик” (2005 СБГ 308); напалок (Гр II 506) “палець печатки, перев'язка на хворому пальці або те ж, що й наперсток”, напальок (1909 Д 170), напалок (1984 ДзПА 137) “перстень”; нап'яток (1958 Дз 135) “задня тверда частина взуття, що охоплює п’яту”; надолок (1930 Із 426) “подол, низ у платті”, надоуок (1894 ГовЗам 196) “частина, пришита до сорочки низом"; наполокъ (1879 Павл 528) “частина одягу, яка пришивається до поли або оздоблення".

За даними фактичного матеріалу, наявні слова, що називають частини кінської упряжі: набідрок (1893 УмСп 1089) “хомут, ремінці біля хомута" (бедро “стегно”); набородок (1984 О I 461) “ремінь вуздечки під шиєю”; а також назви типу: нагробокъ (1622 КартТимч) “надмогильний пам’ятник або камінь”; накоренок (1886 Ж 480) “відросток на корені”, “нижня, коротка частина стовбура, спиляного чи зрубаного при корені дерева” (2004 Матіїв 19); надз(ьо)бок або надзюбок (1927 ПТ 205) “наріст на дзьобові в індика"; насідок (2005 СБГ 321) “покладені під квочку яйця для виведення курчат" від сідало чи сідак "місце для сидіння".

Фіксуються найменування сільськогосподарського реманенту: навилок (Гр II 469; СУМ V 31) “кількість сіна, яку піднято на вилах”, навилок (1912 Верx 237) “держак у вилах" та “купка, копичка сіна” (2003 УГР 675) чи “купа сіна, взята на вила” (2005 СГГ 108); наралок (1987 Корз 169) “залізний наконечник рала, частина плужка для обгортання картоплі” (рало “вид землеробського знаряддя для розпушування зораної землі”); назубок (СУМ V 93) “напилок, яким випилюють зубці, роблять насічку, зазублини і т. ін.”.

Одиничними прикладами представлені найменування риболовецььких приладь: накісток (Гр II 493) “пір'їнка в поплавку” та виробничих: наглинок (1931 ВТ 51) “спеціальний пристрій у керамічному виробництві”; натрубок (1931 ГТ 1122) “кільце”, а також будівельні назви: начілок (1886 Ж 500) “фронтон”; надвірок (ЛексФр 130) “завіс на дверях”.

Конфікс по-...-ок. Розгалуженою в семантичному плані є група іменників з формантом по-...-ок із предметною семантикою. 3 другої половини XVI століття фіксуються назви предметів господарського призначення, які мають розташовуватися біля того, що названо твірною основою, а саме: посторонокъ (1575 АрхЮЗР 1/I 55) “міцний ремінь або мотузок, що 
3'єднує в упряжці шлею чи хомут з орчиком”, пошторонок (2000 ГГ 326) “посторонок шлеї; поножокъ (1627 БерЛекс 85) “наголінник, частина доспіхів, якими покривалися ноги нижче колін”; поденок (1886 Ж 675; 2000 СЗГ II 61) “підстилка під стіг чи оборіг, щоб снопи або сіно не гнили від землі” від дно; подолок (Гр III 244) “нижня частина запаски, даху, снопа від первесла вниз” (дол “низ”), “передній плат; жінки, що його вживали - носили деякі речі, як у сумці” (2004 Бевка 104); поколодок (2000 СЗГ II 65) “пастка для лову мишей або їі частина" від колодка (2000 СЗГ I 236-237) “саморобна пастка для лову мишей”.

Збірні найменування трапляються ще в XIV столітті, проте надалі цей тип іменників поширення не набув. Наприклад: пожытками (1322 АрхЮЗР 1/VI 2-3) “майно, нажите добро (збіжжя)"; поплатки (1408 ССУМ II $195)$ “грошова данина, грошовий податок” (плать “частина, платня”); політок (2000 СЗГ II 66) “усе, посіяне й посаджене в городі; частина поля; спеціально не оброблюване цього року поле; худоба" та "урожай, збір" (2004 Матіїв 40) або “літній урожай” (2005 СГГ 148).

Матеріально-речовинні назви функціонують у сучасній мові, а саме: поярок (СУМ VII 494) “шерсть від першої стрижки молодої вівці, народженої весною” (по ярі “після весни”), паярок (2004 Матіїв 50) “вовна, знята з вівці”; покожушок (2000 СЗГ II 65) “полотно з візерунками; грубе полотно з найгіршого гатунку прядива".

Конфікс па-...-ок. Найменування предметів з цим афіксом фіксуються в новій українській мові: падворокъ (1879 Павл 691) “панська приміська садиба"; паборонок (1886 Ж 595) “бильця в бороні”; пальісок (1912 Верх 243 ) “пристрій для рибалки” (ліса “нитка або шнур на вудилищі, звитий із конського волосся”); патрубок (1931 ВТ 63; СУМ VI 98) “коротка трубка, що служить відводом від основної труби”, “сопло міха, втулка" (2002 СУСГ 157); парінок (1931 СгТ 22) “гравій” (ріна або рінь “дрібні камінці, відшліфовані водою”); пажердок (1931 ГТ 124) “короткий натрубок на жердині”; паріжок (1984 О II 41) “парожок, коротка кроква, яку додають до звичайної для розширення даху”; паклинок (1984 ДзПА 25; 2000 СЗГ II 22) “клин, за допомогою якого кріпиться коса на кіссі”.

Конфікс над-...-ок. Перший субстантив із морфемою над-...-ок, за нашими матеріалами, фіксується в XVII столітті: надгробокъ (1648 КартТимч) “пам'ятник над могилою або камінь”, надгробок (СУМ V 65) “пам’ятник, камінь, плита і т. ін., встановлені на могилі”. Саме в цей час починає формуватися й загальне словотвірне значення типу: “те, щзо по відношенню до предмета, названого твірною основою, займає у просторі положення згори (над ним)"”. Пізніше виникло ще кілька похідних такого плану, які окремих груп не складають: надчубокъ (1879 Павл 509) “капелюх або щось інше, що виконує функцію капелюха" (чуб “передня частина волосся або все волосся на голові в людини”); надтінок (1886 Ж 496) “тент, натягнутий зверху на палицю або на щось інше для створення затінку”; надкрилок (1931 ВТ 51) 
“частина крила у вітряку”, “елемент невода” від крило “одна із сіток невода, бокове полотнище”; надколінок (СУМ V 71) “плоска округла кістка, розміщена спереду нижнього колінця стегна"; надосник (1990 ТЛП 61) “дерев’яний брус, укріплений зверху на металевій осі воза”.

Конфікс ви-...-ок. Іменники з ви-...-ок-це найменування предметів, які містять деякі ознаки з тих, щуо притаманні названим мотивувальним словом, наприклад: вижолобок (1886 Ж 74) “пристрій для годівлі худоби, неглибокий жолоб” (жолоб “те ж, що і ясла”); виріжок (1886 Ж 84) “частина чого-небудь, що видається наперед, виступ” від ріг; вибрудок (1882 ФП 33) “гуща, брудний осадок” (бруд “грязь, грязюка”); вишкварок (1886 Ж 93) “дуже малий обсмажений шматок сала” (те ж, що і шкварка); вибороздок (1984 О I 96) “остання скиба під час оранки в розгін” (борозда “слід, який лишається на землі після оранки”).

Одиничним прикладом представлене найменування предмета, щзо $\epsilon$ результатом дій, виконаних іншим предметом, який названий твірною основою: вигніток (1909 Д 37) “вичавки з винограду, з конопляного сім’я макуха або щось інше, що побувало під гнітом” (гніт “тягар”).

Конфікс від-...-ок. Найменування предметів, які містять у собі деякі ознаки того, що названо вивідною основою, або є частиною того, що називає мотивувальне слово, за нашими даними, фіксуються в новій українській мові і представлені дериватами з морфемою від-...-ок. Наприклад: відгілок (1928 Елек 76) “те, що відводиться від основної лінії, відгалуження”; відринвок (1931 ВТ 60) “відгалуження труби для стоку води” (ринва “труба для стоку води”); одлясок (1958 Дз 48) “частина ляси біля кітця, яка затримує рибу і не дає їй змоги вийти з кітця" (ляса “щит із міцних, очищених від листя очеретин”, кітещъь “загорода із очеретяних ляс для вилову риби”). Відтінок збірності в семантиці має десубстантив віджилок (1971 И 89) "корисні копалини, які розташовані на віддалі від основної лінії, або невелика жила, що відгалужується від основної”.

Конфікс $\boldsymbol{y}$-...-ок. Деривати 3 цією морфемою є найменуваннями таких предметів: ушулок (1974 Лис 222) “закопаний у землю стовп у стіні будівлі або огорожі з видовбаним глибоким пазом, у який вставляються дошки, обтесані колоди” (жула “стовб в огорожі, у який вставлені дошки”), “перша відрізана від паляниці скибка” (2000 СЗГ II 219); ушийок (Гр IV 371) “шкіра на потилиці або перешийок”; участок (1984 O I 325) “ділянка землі, відокремлена від інших" (часть “частина”); ускалок (1984 О II 321) “частина скалки, тріска, якою світили" від скалка; укуньок (2000 СЗГ II 218) “ковзан”, пор. кунька (2000 СЗГ І 268) “ковзан”.

Конфікс з-...-ок. Засвідчено предметні найменування 3 формантом з...-ок, наприклад: збанок (2005 СБГ 152) “особливої форми глечик для свіжого молока, посудина для зберігання води в полі" (баня “спеціальна скляна посудина”); зголовок (1920 Яв 290) “подушка поверх осі у возі”; 
скравок (1900 ДолГов 119) “окраєць хліба", злобок (АУМ II 89) “те саме”, пор. лоб (СУМ IV 535) “передня частина чого-небудь”.

Конфікс недо-...-ок. Назви предметів (рідко - тварин), які мають лише деякі ознаки чи властивості того, щчо названо твірною іменниковою основою, представлені дериватами, які утворилися за допомогою афікса недо-...-ок: недомірок (СУМ V 295) "те, що не відповідає звичайній мірі, менше за міру”, “риба, менша за середню величину” (Гр II 545); недошубокъ (1879 Павл 557) “верхній одяг з низької якості хутра або полушубок”; недоуздок (1886 Ж 509) “оброть — вуздечка без вудил і залізних мундштуків, які вставляють у рот коневі, для прив'язування у хліві”.

Конфікс су-...-ок. Назви предметів представлені небагатьма іменниками $з$ формантом $c y-.$. -ок, наприклад: суголовок (Гр IV 225) “частина вуздечки біля вудил - те, що надягається на голову коня", “потовщена частина дерев'яної осі” (1990 ТЛП 60), “дерев’яний брус, укріплений наглухо зверху на металевій осі воза” (2004 Матіїв 28), сугловок (Гр IV 225) “вугол скрині”; сукрайок (ЛексФр 231) “те, що прилягає до краю, окраєць”.

Конфікс пере-...-ок. Найменування предметів домашнього вжитку, які неповністю виявляють ознаки чогось, названого мотивувальним іменником: перескринок (1909 Д 211) “шухляда у скрині, відгороджений жолобець на дрібні речі"; переситок (ЛексФр 164) “сито із сіткою, у якій не дуже дрібні дрючки”; перехресток (1984 ДзПА 63) “поперечна частина хреста або предметів, подібних до хреста".

Конфікс без-...-ок. Назва предмету господарського вжитку - це похідне слово із зазначеним афіксом: безденок (1886 Ж 17) “підставка під вулик, у якій не роблять із обох кінців дна”, бездонок (1920 Яв 20) “те саме”.

Конфікс через-...ок. В українській мові існує лише один дериват такої структури із лексико-словотвірним значенням "предмет, який пролягає через щось, назване твірною основою”: черезсіделок (1990 ТЛП 151) “ремінь, який тримає упряж на сідлі" (через сідло).

Таким чином, у пам'ятках української мови XIV-XXI ст. зафіксовано значну кількість похідних конфіксальних іменників, які є назвами різноманітних предметів, що виникли в певний період часу та використовувалися на певній території України. Як показує зібраний фактичний матеріал, описані деривати, утворені за допомогою сімнадцяти конфіксів з другим компонентом -ок, мають характерні особливості структури та семантики.

\section{Список скорочень джерел}

АрхЮЗР Архив Юго-Западной России, издаваемый Временною Комиссиею по разбору древних актов. - К., 1859-1914. - Ч. 1-8.

АО Акти села Одрехови / [Відп. ред. Л.Л. Гумецька]. - К.: Наукова думка, 1965. - $190 \mathrm{c}$.

АУМ Атлас української мови. - К., т.1. - 1984. - 498 с., т.2. $-1988 .-520$ с.

Бат Верхратський І. Говір Батюків / І. Верхратський. - Львів, 1912. - 308 с.

Бевка Бевка О. Словник-пам'ятник. Діалектний словник села Поляни Мараморошського комітату / Олекса Бевка. - Ніредьгаза, 2004. - 178 с. 
БерЛекс Лексикон словенороський Памви Беринди. Надр. 3 вид. 1627 року фотомеханічним способом / [Підгот. тексту і вступ. стаття В. В. Німчука]. - K., 1961. -272 c.

Б-Н Білецький-Носенко П. Словник української мови / П. БілецькийНосенко [Підгот. до вид. В. В. Німчука].- К., 1966. - 421 с.

БукГов Матеріали до словника буковинських говірок. - Вип. 1-6. - Чернівці, 1971-1979.

Вас Василенко В. И. Опыт толкового словаря народной технической терминологии по Полтавской губернии. Отделы I, II, III. Кустарные промыслы, сельское хозяйство и землеведение, народныя поговорки и изречения / В. И. Василенко. - Харьковъ, 1902. - 80 с.

Верx Верхратський I. Знадоби до пізнання угорсько-руських говорів / I. Верхратський // ЗНТШ - 1899. - Т. 27-30; 1901. - Т. 40,44; 1902. - Т. 45.

BT Шелудько I. М. Практичний словник виробничої термінології / I. М. Шелудько. - Харків, 1931. - 110 с.

ГГ Гуцульські говірки. Лінгвістичні та етнолінгвістичні дослідження / Відп. ред. Закревська Я. - Львів, 2000. - 364 с.

ГовЗам Верхратський І. Говір замішанців / I. Верхратський // ЗНТШ - 1894. T.3. - C. 153-210.

Гр Словарь української мови. Зібрала редакція журналу "Киевская старина" / [Упорядкував 3 дод. власного матеріалу Б. Грінченко]. - Т.1-4. К., 1907-1909.

Д Дубровський В. Словник українсько-московський / В. Дубровський. - 5 вид. - К., без року. -361 с.

Дз Дзендзелівський Й. О. Словник специфічної лексики говірок нижнього Подністров'я / Й. О. Дзендзелівський // Лексикографічний бюлетень. Вип. VI, 1958. - С. 35-55.

ДзПА Дзендзелівський Й.О. Програма для збирання матеріалів до лексичного атласу української мови / Й. О. Дзендзелівський. - К., 1984. - 308 с.

ДM Ділова мова Волині і Наддніпрянщини XVII ст.: Збірник акт. документів / [Відп. ред. В. В. Німчук]. - К., 1981. - 316 с.

ДНМ Ділова і народнорозмовна мова XVIII століття / [Підгот. до вид. В. А. Передрієнко]. - К., 1976. - 415 с.

ДолГов Верхратський І. Про говор долівський / I. Верхратський // ЗНТШ. - Т. 35-36, 1900. - С. 1-127.

Ж Желеховский Е. Малорусско-німецкий словар / Е. Желеховский. - Т.12. - Львів, 1886. - 1117 с.

Закр Закревський Н. В. Старосвһтский бандуриста. Словарь малороссійскіхъ идіомовъ / Н. В. Закревський. - М., 1861. - С. 247-628.

Зел Методичні вказівки 3 діалектології української мови. Словник східнополіського говору / [Підгот. до вид. А. Зеленько]. - Луганськ, 1990. - 78 с.

И У Ураинско-русский словар / [Под. ред. В. С. Ильина]. - К., 1971. $1064 \mathrm{c}$.

ІвШ Іваницький С. Російсько-український словник / С. Іваницький, I. Шумлянський. - В 2-х томах. - Липськ-Харків, 1925.

Із Ізюмов О. Українсько-російський словник / О. Ізюмов. - Харків, 1930. $-980 \mathrm{c}$.

IKIC Індекс картотеки словника української мови XVI - першої половини XVII ст. Зберігається в інституті українознавства ім. І. Крип'якевича 
АН України в м. Львові.

Карт- Картотека до історичного словника українського языка / [Укл.

Тимч Є.Тимченко]. - Зберігається в інституті українознавства ім. І. Крип'якевича АН України в м. Львові.

Корз Корзонюк М. М. Матеріали до словника західноволинських говірок / М. М. Корзонюк // Українська діалектна лексика. - К.: Наукова думка, 1987. - С. 62-267.

ЛАЗ Дзендзелівський Й. О. Лінгвістичний атлас українських народних говорів Закарпатської області УРСР (лексика) / Й. О. Дзендзелівський. Ч. 1-2. - Ужгород, 1958-1960.

Левч Левченко М. Опыт русско-украинского словаря / М. Левченко. - К., 1874. - 190 c.

ЛексФр Лексика поетичних творів Івана Франка. - Львів, 1990. - 197 с.

Лис Лисенко П. С. Словник поліських говорів / П. С. Лисенко. - К.: Наукова думка, 1974. - 257 с.

Ліпкевич Ліпкевич І. Г. Словник рибальської лексики / І. Г. Ліпкевич // Ліпкевич I. Г. Рибальська лексика в українських говірках Нижньої Наддніпрянщини. - Дис. на здоб. ... канд. філол. наук. - Запоріжжя, 1993. - С. 212-235.

ЛЛ Полное собрание русских летописей. Т. 1. Лаврентьевская и Суздальская летопись по академическому списку. - М.: Изд-во восточной литературы, 1962. - 581с.

Матіїв Матіїв М. Д. Методичні поради і матеріали для діалектологічної практики студентів-філологів / М. Д. Матіїв. - Сімферополь: Доля, 2004. - 79 с.

Мельн Мельничук О. С. Словник специфічної лексики говірки села Писарівки (Кодимського району Одеської області) / О. С. Мельничук // Лексикографічний бюлетень Вип.2. - К., 1952. - С. 67-99.

О Онишкевич М. Й. Словник бойківських говірок / М. Й. Онишкевич. Ч. 1-2. К., 1984.

Павл Павловскій А. Грамматика малороссійскаго нарһчія. Краткій малороссійскій словарь / А. Павловскій. - СПб, 1818. - 114 с.

ПТ Словник природничої термінології. - К., 1927. - 262 с.

СБГ Словник буковинських говірок / [За заг. ред. Н. В. Гуйванюк]. - Чернівці: Рута, 2005. - 688 с.

СГГ Піпаш Ю. О. Матеріали до словника гуцульських говірок (Косівська Поляна і Росішка Рахівського району Закарпатської області) / Ю. О. Піпаш, Б. К. Галас. - Ужгород, 2005. - 266 с.

СгТ Сабалдир Г. О. Практичний словник сільськогосподарської термінології / Г. О. Сабалдир. - Харків, 1931. - 99 с.

СЗГ Аркушин Г. Л. Словник західнополіських говірок / Г. Л. Аркушин. У 2x томах. - Луцьк: Редакційно-видавничий відділ “Вежа" Волинського державного університету ім. Лесі Українки, 2000.

Сизько Сизько А. Т. Словник діалектної лексики говірок сіл південно-східної Полтавщини / А. Т. Сизько. - Дніпропетровськ, 1990. - 100 с.

СлЛекс Лексикон латинський $Є$. Славинецького. Лексикон словено-латинський Є. Славинецького та А. Корецького-Сатановського / [Підгот. до вид. В. В. Німчук]. - К.: Наукова думка, 1973. - 541 с.

СМН Афанасьевъ-Чужбинскій И. Словарь малорускаго нарһчія / И. Афанасьевъ-Чужбинскій. - К., 1855. - 175 с.

СПГ Ващенко В. С. Словник полтавських говорів / В. С. Ващенко. - Харків, 
1960. - Вип. 1. - 107 с.

ССУМ Словник староукраїнської мови XIV-XV ст. - Т.1-2. - К., 1977-1978. 630 c., $591 \mathrm{c.}$

СУМ Словник української мови. Т.1-11. - К., 1970-1980.

СУСГ Глуховцева К. Словник українських східнослобожанських говірок / К. Глуховцева, В. Лєснова, І. Ніколаєнко, Т. Терновська, В. Ужченко. Луганськ, 2002. - 234 с.

ТЛП Никончук М. В. Транспортна лексика правобережного Полісся в системі східнослов'янських мов / М. В. Никончук, О. М. Никончук. - К., 1990. - 291 c.

Торг Торгівля на Україні XIV - cep. XVII століття. Волинь і Наддніпрянщина. - К.: Наукова думка, 1990. - 406 с.

УГР Павлюк М. Українські говори Румунії. Діялектні тексти / М. Павлюк, I. Робчук. - Едмонтон-Львів-Нью-Йорк-Торонто, 2003. - 784 с.

УмСп Словарь росийско-украинский / М. Уманець і А. Спілка. - Т.1-2. Львів, 1893-1894. - 318 с., 285 с.

УРС1926 Українсько-російський словник / А. Ніковський. - К., 1926. - 864 с.

ФП Словник живої народної, письменної і актової мови руських югівщан Російської і Австро-Венгерської Цесарії / Сост. Фортунат Пискунов. Изд. 2-е испр. и знач. пополн. - К., 1882. - 309 с.

Яв Яворницький Д. І. Словник української мови / Д. І. Яворницький. Т. 1. - Катеринослав, 1920. -412 с. 